\title{
Physics Student-Teachers' Challenges during Teaching Practice in Secondary Schools and Their Solutions: A Study of Federal University of Agriculture Makurdi
}

\author{
Atsuwe, B. $\mathbf{A}^{\mathbf{1}}$, Nomji, E, $\mathbf{V}^{2}$ \\ ${ }^{1,2}$ Department of Science Education, College of Agricultural and Science Education, Federal University of \\ Agriculture Makurdi, Benue state, Nigeria. \\ Corresponding Author: Atsuwe, B. A
}

\begin{abstract}
This study examined the challenges faced by student-teachers during teaching practice and their possible solutions in the Federal University of Agriculture Makurdi, Benue state, Nigeria. To achieve this, the descriptive survey research design was adopted. Four Research questions and four Research hypotheses guided the study .The sample of the study was drawn from five degree options out of the eight degree options in the College of Agricultural and science Education in the study area. Primary data were used for the study specifically obtained using well-structured questionnaire. Two hundred copies of the questionnaires were administered on the respondents and survey data analysed using descriptive statistics and Chi-square test. Results of the analyses showed that classroom management significantly affect studentteachers' performance during teaching practice in secondary schools. The results revealed that curriculum development and instruction significantly affect student-teachers' during their practice year. The result also revealed that supervision of student-teachers' does greatly affect students' teachers during their teachers during their teaching practice. The study recommends that Proper and maximal attention should be given to the classroom management by student-teachers' in order to achieve the specific objectives at the end of the lesson in the classroom .There is need for the government to provide good library facilities and laboratories.
\end{abstract}

Keywords- student-teachers', Teaching practice, Challenges, Secondary Schools.

\section{INTRODUCTION}

Higher education institutions offering teacher education programs in Nigeria are required in terms of education policies to ensure that their students are placed in schools where they can interact with the realities of classroom teaching and the broader school environment. In the classroom, the teaching and learning are considered social activities that imply relationships between not only the teachers and students, but also between these parties and materials, equipments, classroom environment and curriculum as well as is asserted by wright (as cited in Saricoban, 2010). The business of teachers is to help students achieve higher standard of knowledge, ability, skills, and moral character (lawal, Adesegun \& Olatunji, 2015).

Teaching is the process of anyone aiding another individual to learn (Jokthan, 2012). A Teacher is an individual with special skills and abilities. In the long past, societies lack institutions offering instructions in the principles and practice of teaching. The dearth of teachers and teacher education grew with the rise of democratic principles during the $17^{\text {th }}$ and $18^{\text {th }}$ centuries. It was argued that the political, social and 
economic development of nations could be best achieved through education of the individual citizen. The earliest known educational institution to offer systematic program of teacher training was the institution of the Brothers of the Christian Schools established in 1685 in Reims, France by the French Priest Saint John de la Salle, (Brickman,2009).

Teacher education is critical in nation building because it produces the right calibre of teachers to deliver quality education for national development. Lawal et.al (2015) posit that the improvement in education depends largely on the qualification and ability of a teaching profession generally and the human pedagogic and technical qualities of the individual teachers. Education is the key to human capital development and the system must be subjected to reforms and repositioning as static education system do not transform societies (Okolo, 2013). Tillema, Smith and Leshem (2011) are of the view that during the teaching practice, student teachers' experience a learning situation that is unique and different from campus-based learning as they are called upon to respond to new circumstances. In the same vein, Komba and Kira (2013) noted that during teaching practice, student teachers' observe subject teachers' work so as to learn about teachers' skills, strategies and classroom achievements. It is also the time when they evaluate their own teaching experiences through interactions with teachers' and lecturers and, through selfreflection, implement a variety of approaches, strategies and skills with a view to bringing about meaning learning and enhance national development ((Komba \& Kira, 2013).

The fallen standard of education in Nigeria has reached an alarming stage yet education is the bedrock of development. Iniobong, (2009) Opined that the future of any nation depends on the quality of her teachers. The national policy on education (2013) stated that no educational system can rise above the level of its teaching staff.
This shows the role of the teachers and the teacher education programmes in national development. With the introduction of the Universal Basic Education (UBE) in 1976, only well trained teachers can successfully translate the objectives of UBE to reality.

The teaching practice is one of the most important aspects of teachers training programme in Nigeria aimed at exposing the student teachers to field to carry out the theoretical knowledge and experience into practice in real classroom situation under the supervision of a qualify teacher. Many student teachers get agitated about entering the classrooms to take up teaching tasks in unfamiliar environment. According to Kiggundu and Nayimuli (2009) such mixed feelings can contribute to the making or discouraging of student teachers. The inability to fully realize the objectives of teaching practice or the inability of student teachers to perform to expectation can be attributed to certain challenges or inadequacies of the programme. The researcher sought to find the challenges faced by student teachers during teaching practice and to suggest some possible solutions to these problems.

The study is aimed at investigating the challenges facing student teachers during teaching practice exercise in secondary schools and their solutions. Specifically, the study seeks to:

Determine the classroom management challenges facing student teachers' during teaching practice exercise in secondary schools.

Determine the curriculum development and instruction challenges facing student teachers during teaching practice exercise in secondary schools.

Determine the supervisory challenges facing student teachers during teaching practice exercise in secondary schools.

The rest of this paper is organised as follows, section contains the introduction, section II contains the related work of challenges faced by student-teachers during teaching practice, section III contains the 
methods used in investigating this challenges, section IV contains result of findings and their discussion and finally section $\mathrm{V}$ contains conclusion and suggestions for further studies

\section{Research Questions}

The following research questions are developed to guide the study.

1. What are the challenges of classroom management faced by student teachers during teaching practice exercise in secondary schools?

2. What are the curriculum developments and instruction challenges faced by student teachers during teaching practice exercise in secondary schools?

3. What are the supervisory challenges faced by student teachers during teaching practice exercise in secondary schools?

\section{Research Hypothesis}

In relation to the above research questions, the following hypothesis will be stated:-

1. Classroom management does not significantly affect student teachers during teaching practice exercise in secondary schools.

2. Curriculum development and instruction does not significantly affect student teachers during teaching practice exercise in secondary schools.

3. Supervision of student teachers does not significantly affect student teachers during teaching practice exercise in secondary schools.

\section{RELATED WORK}

Okobia, Augustine and Osagie (2013) also conducted a study on the Perceived Challenges Faced by StudentTeachers during Teaching Practice Exercise.The study revealed that fifteen out of the twenty one items were perceived by majority of student teachers as major challenges faced during teaching practice exercise. Also it was found that school location had no influence on the challenges faced by student teachers.

Azeem (2011) conducted a study on problems of prospective teachers during teaching practice. The study identified that majority of the schools do not prepared the timetable for the pupil teachers, also, Pupil teachers are not imparted practical training of different methods of teaching before they are sent for teaching practice. In addition, Majority of the students are not informed about the rules and regulations of the practising schools.Proper planning for teaching practice may be made before its commencement like consent of students, transport facility, orientation of teaching practice, available facilities, and school rules and regulations; Preparation of a feasible timetable for the pupil teachers in collaboration with school administration; Pupil teachers should be imparted practical training in using different methods of teaching.

\section{RESEARCH METHODOLOGY}

This study used descriptive research design to determine Student-Teachers' challenges during teaching practice in secondary schools and their solutions: A study of Federal University of Agriculture Makurdi.

The sample and sampling techniques is drawn from the five degree options which were selected randomly from the College of Agricultural and Science education, Federal University of Agriculture Makurdi.

The sampling technique was purposive sampling method. The purposive sampling method was adopted by the researcher to obtain the rightful respondents who will most likely contribute appropriate data required for the study. The researcher selected twenty (20) students in $300 \mathrm{~L}$ and 400L from each degree option to answer the questionnaire and the overall sample on the final analysis turn out to be two hundred (200) respondents.

The data collected were analysed using the mean and standard deviation to answer the research questions and Chi- 
Atsuwe, B. A et.al. Physics student-teachers' challenges during teaching practice in secondary schools and their solutions: a study of Federal University of Agriculture Makurdi.

Square to test the hypotheses at $1 \%$ level of significance.

In taking decisions, any mean below 3.00 will be rejected and those above 3.00 will be accepted. In testing the hypotheses, where the calculated value Chi-Square is the less than the critical or table value, the hypotheses will be accepted confirming the theory of significant level of testing. If the calculated value of Chi-Square exceed the critical or table value. The hypotheses will be rejected.

\section{RESULTS AND DISCUSSION}

Research Question 1: What are the classroom challenges faced by studentteachers' during teaching practice exercise in secondary schools.

Table 1: Mean and Standard deviation of respondents based on classroom management.

\begin{tabular}{|c|c|c|c|c|c|c|c|c|c|}
\hline $\mathbf{S} / \mathbf{N}$ & Classroom management & $\mathbf{S A}$ & $\mathbf{A}$ & $\mathbf{U N}$ & $\mathbf{D}$ & SD & $\bar{X}$ & Sd & REMARK \\
\hline 1 & $\begin{array}{l}\text { Does poor arrangement of sitting positions of students affect student- } \\
\text { teachers' during teaching practice? }\end{array}$ & 65 & 49 & 11 & 16 & 22 & 3.73 & 1.41 & Accepted \\
\hline 2 & $\begin{array}{l}\text { Does controlling of students movement in and out of classroom affect } \\
\text { student-teachers' during teaching practice? }\end{array}$ & 42 & 55 & 17 & 25 & 24 & 3.21 & 1.41 & Accepted \\
\hline 3 & $\begin{array}{l}\text { Do controlling noise making in class affect student-teachers' during } \\
\text { teaching practice? }\end{array}$ & 52 & 30 & 20 & 50 & 11 & 3.38 & 1.38 & Accepted \\
\hline 4 & $\begin{array}{l}\text { Does improvisation in teaching affects student-teachers' during } \\
\text { teaching practice? }\end{array}$ & 59 & 42 & 15 & 23 & 24 & 3.55 & 1.46 & Accepted \\
\hline 5 & $\begin{array}{l}\text { Do set inducements in students affect student-teachers' during } \\
\text { teaching practice? }\end{array}$ & 39 & 38 & 37 & 22 & 27 & 3.25 & 1.39 & Accepted \\
\hline 6 & $\begin{array}{l}\text { Does writing on the chalkboard/whiteboard affects student-teachers' } \\
\text { during teaching practice }\end{array}$ & 11 & 29 & 8 & 91 & 24 & 2.46 & 1.14 & Rejected \\
\hline \multicolumn{2}{|c|}{ Average } & & & & & & 3.26 & 1.37 & Accepted \\
\hline
\end{tabular}

From table 1: The table reveals that items $1,2,3,4,5$ respectively were accepted upon by the respondents because those items receive the mean of 3.00 above which is within the acceptable range and item 6 was rejected by the respondents.

Apart from the item 6, all other items have mean of 3.00 above which shows that respondents accepted that those items contribute challenges to the classroom management during teaching practice exercise in secondary schools.

Research Question 2: What are the curriculum developments and instruction challenges faced by student teachers during teaching practice exercise in secondary schools?

Table 2: mean and standard deviation of respondents based on curriculum development and instruction.

\begin{tabular}{|c|c|c|c|c|c|c|c|c|c|}
\hline $\mathbf{S} / \mathbf{N}$ & Curriculum Development and instructions & SA & $\mathbf{A}$ & $\mathbf{U N}$ & D & SD & $\bar{X}$ & Sd & Remark \\
\hline 7 & $\begin{array}{l}\text { Do non availability of subject curriculum affects student-teachers' } \\
\text { during practice? }\end{array}$ & 45 & 49 & 34 & 23 & 12 & 3.56 & 1.23 & Accepted \\
\hline 8 & $\begin{array}{l}\text { Does inability of student-teachers' to use instructional materials properly } \\
\text { affects student-teachers' during teaching practice? }\end{array}$ & 41 & 42 & 21 & 31 & 28 & 3.23 & 1.45 & Accepted \\
\hline 9 & $\begin{array}{l}\text { Does inability of student teacher to apply right teaching skills affects } \\
\text { student-teachers' during teaching practice? }\end{array}$ & 21 & 29 & 30 & 43 & 40 & 2.68 & 1.24 & Rejected \\
\hline 10 & $\begin{array}{l}\text { Do non availability of relevant textbooks affects student-teachers' during } \\
\text { teaching practice? }\end{array}$ & 43 & 40 & 21 & 24 & 35 & 3.20 & 1.51 & Accepted \\
\hline 11 & $\begin{array}{l}\text { Does non availability of curriculum guidelines affects student-teachers' } \\
\text { during practice? }\end{array}$ & 28 & 23 & 36 & 35 & 41 & 2.77 & 1.41 & Rejected \\
\hline 12 & $\begin{array}{l}\text { Does Writing of lesson plan affects student-teachers' during teaching } \\
\text { practice? }\end{array}$ & 37 & 40 & 18 & 28 & 40 & 3.04 & 1.52 & Accepted \\
\hline 13 & $\begin{array}{l}\text { Does giving of evaluation affects student-teachers' during teaching } \\
\text { practice? }\end{array}$ & 52 & 26 & 22 & 27 & 36 & 3.19 & 1.56 & Accepted \\
\hline 14 & $\begin{array}{l}\text { Does marking of evaluation affects student-teachers' during teaching } \\
\text { practice? }\end{array}$ & 35 & 30 & 25 & 38 & 35 & 2.95 & 1.46 & Rejected \\
\hline 15 & $\begin{array}{l}\text { Does inability of student teacher to master subject matter affects student- } \\
\text { teachers' during teaching practice? }\end{array}$ & 23 & 19 & 31 & 46 & 43 & 2.59 & 1.36 & Rejected \\
\hline \multicolumn{2}{|c|}{ Average } & & & & & & 3.02 & 1.42 & Accepted \\
\hline
\end{tabular}

From table 2: The results above represents the mean responses of the respondents on the curriculum development and instruction challenges faced by student- teachers' during teaching practice exercise. Items 9, 11, 14 and 15 were rejected since they had mean values less than the bench mark mean of 3.00 . On the other hand, 
items $7,8,10,12$, and 13 were all accepted as challenges faced by student teachers' during teaching practice since they had mean values greater than the bench mark mean of 3.00 .
Research Question 3: What are the supervisory challenges faced by student teachers during practice exercise in secondary schools?

Table 3: Mean and Standard deviation of respondents on supervisory challenges.

\begin{tabular}{|c|c|c|c|c|c|c|c|c|c|}
\hline $\mathbf{S} / \mathbf{N}$ & Supervision & $\mathbf{S A}$ & $\mathbf{A}$ & $\mathbf{U N}$ & D & SD & $\bar{X}$ & Sd & REMARK \\
\hline 16 & Do supervisors spent only few minutes in your class. & 51 & 41 & 15 & 27 & 29 & 3.36 & 1.50 & Accepted \\
\hline 17 & Were supervisors impatience to go through the lesson plan.? & 24 & 32 & 11 & 51 & 45 & 2.63 & 1.44 & Rejected \\
\hline 18 & $\begin{array}{l}\text { Does lack of cordial relationship between supervisors and student- } \\
\text { teachers' affects student-teachers during teaching practice? }\end{array}$ & 50 & 48 & 19 & 21 & 25 & 3.47 & 1.43 & Accepted \\
\hline 19 & $\begin{array}{l}\text { Does non cooperative attitudes of regular teachers with student- } \\
\text { teachers' affects student-teachers' during teaching practice? }\end{array}$ & 32 & 30 & 20 & 40 & 41 & 2.83 & 1.48 & Rejected \\
\hline 20 & $\begin{array}{l}\text { Does lack of feedback from supervisors on student-teachers' } \\
\text { performance affects student-teachers' during teaching practice? }\end{array}$ & 47 & 32 & 12 & 38 & 34 & 3.12 & 1.55 & accepted \\
\hline \multirow[t]{2}{*}{21} & $\begin{array}{l}\text { Non supervision by some supervisors affect student-teachers during } \\
\text { teaching practice? }\end{array}$ & 32 & 30 & 23 & 38 & 40 & 2.85 & 1.47 & Rejected \\
\hline & average & & & & & & 3.04 & 1.48 & Accepted \\
\hline
\end{tabular}

The table above represent the mean responses of the respondents on the supervisory challenges facing student teachers during teaching practice exercise. So far, items 16,18 and 20 had mean greater than the benchmark mean and were hence accepted. Items 23, 25, and 27 all had mean less than the benchmark mean and were rejected. The average mean response was 3.04 which is above the benchmark mean and therefore was accepted.

Hypothesis 1: Classroom management does not significantly affect student-teachers' during teaching practice exercise in secondary schools.

Table 4: Chi-Square analysis testing hypothesis two.
\begin{tabular}{|c|l|l|l|l|l|l|}
\hline Variables & $\mathbf{N}$ & Df & Ls & Crit $\boldsymbol{\chi} \mathbf{2}$ value & Cal $\boldsymbol{\chi} \mathbf{2}$ value & Decision \\
\hline 6 & 163 & 20 & 0.01 & 37.57 & 198.85 & Rejected \\
\hline
\end{tabular}

The results in the table 3 above show that the calculated value of Chi-Square (i.e. 198.85) is greater than the critical value (i.e. $37.57)$ at 0.01 significant value. Therefore, the hypothesis is rejected confirming the theory of significant testing. Thus, the hypothesis being rejected shows that classroom management is among the challenges faced by student-teachers' during teaching practice exercise in secondary schools. This corresponds with Okonkwo \& Chikwelu (2011) which states that within the student teaching practice experience, students teachers encounter difficulties that result to problems associated with the classroom management. Factors such as poor arrangement of sitting positions students, controlling of students movement, controlling of noise making, Improvisation in teaching and set inducing students were seen as some of classroom challenges faced by student teachers during their teaching practice exercise.

Hypothesis 2: Curriculum development and instruction does not significantly affect student teachers during teaching practice in secondary schools.

Table 5: Chi Square analysis testing hypothesis three.

\begin{tabular}{|c|l|l|l|l|l|l|}
\hline Variables & $\mathbf{N}$ & $\mathbf{D f}$ & Ls & Crit $\boldsymbol{\chi} \mathbf{2}$ value & Cal $\boldsymbol{\chi} \mathbf{2}$ value & Decision \\
\hline 9 & 163 & 32 & 0.01 & 53.49 & 98.92 & Rejected \\
\hline
\end{tabular}

From the table above, the calculated Chi-Square value 98.92 is greater than the critical Chi-square value 53.49 hence, the null hypothesis which states that the curriculum development and instruction does not significantly affect student teachers during teaching practice is rejected. This implies that curriculum development and instruction has significant impact on students teachers performance during 
teaching practice exercise in secondary schools.
Hypothesis 3: Supervision does not significantly affect student teachers during teaching practice exercise in secondary schools

Table 6: Chi-Square analysis testing the hypothesis four.

\begin{tabular}{|c|l|l|l|l|l|l|}
\hline Variables & N & Df & Ls & Crit $\boldsymbol{\chi} \mathbf{2}$ value & Cal $\boldsymbol{\chi} \mathbf{2}$ value & Decision \\
\hline 6 & 163 & 20 & 0.01 & 37.57 & 54.95 & Rejected \\
\hline
\end{tabular}

Table 6 above shows that the calculated Chi_square value 54.95 is greater than the critical or tabulated value 37.57 at 0.01 significant value. The null hypothesis which state that supervision does not affect student teachers during teaching practice exercise in secondary schools is rejected. This implies that supervision does significantly affect student teachers during their teaching practice exercise in secondary schools. This is in line with findings of Bechuke et al (2013) which revealed that university assessors are not consistent in their duties as supervisors

\section{CONCLUSION}

The study confirms that within the student-teachers' teaching practice experience, student-teachers' encounter difficulties that result to problems associated with the classroom management, environment, curriculum development and instructions and supervision.

Classroom management represents one of the major challenges identified by student-teachers' during their teaching practice experience. Classroom management is challenging for student-teachers' due to the difficulty in providing realistic situation in the educational studies classroom prior to students teaching. Contributing to this are classroom dynamics that vary widely depending on the level of the classes, the time of the day and the students. This approach provides a practical approach that still falls short of stimulating the experience but exposes student-teachers' to real-life situations, expectations strategies in regard to dealing with classroom management.

The attainment of quality education will be a mirage without adequate preparation of manpower that will dispense the knowledge. This calls for serious consideration of stipulated strategies to be adopted in tackling the challenges which student-teachers face.

\section{Recommendations/ Solutions}

In the light of the findings of this study, the following recommendations are made:

1. Proper and maximal attention should be given to the classroom management by student-teachers' in order to achieve the specific objectives at the end of the lesson in the classroom.

2. There is need for the government to provide good library facilities and laboratories.

3. Adequate curriculum materials and guidelines, facilities, reference materials like textbooks should be made available to facilitate effective and efficient teaching and learning.

4. Student-teachers' should be sent to high quality schools with enabling learning environment.

5. Schools of education and colleges should organize the teaching practice exercise very well so as to give the best professional practice to the trainee teachers.

6. A proper orientation for student teachers should be carried out using efficient means of communication like; seminars, workshops, conferences and discussion before they go for teaching practice.

7. Student teachers should participate at least once or twice in micro-teaching exercises as a way of exposing them to teaching practice.

8. The university should appeal to the government, non-governmental organizations like the private sector, individuals and industries to assist in supplementing educational materials and 
learning resource that would prepare the students teachers.

9. The cooperating teachers should be trained on their roles while working with the student teachers.

10. The government should provide finance inform of stipend for student teachers so as to boost their up keep and their attitude towards the profession.

\section{Further Studies}

This study serves as a basis for further research study on student-teachers' challenges during their teaching practice in secondary schools.

Similar studies should be conducted in other states of the federation so as to bring about improvement in the performance of student-teachers' during their teaching practice exercise and to create more pages for research and academic activities.

\section{Acknowledgement: None}

\section{Conflict of Interest: None}

\section{Source of Funding: None}

\section{REFERENCES}

1. Azeem, M. (2011), problems of prospective teachers during teaching practice:

2. Brickman, W. (2009). Teacher training. Redmond WA Microsoft Cooperation 2008

3. Iniobong, A.U (2009). Attitude of student teachers towards teaching practice in the University of Port Harcourt River State. Nigeria. Journal of Emerging Trends in Educational Research and policy studies 2(1) 4-46

4. Jokthan, E.T (2012). Teachers and Teacher Education in the $21^{\text {st }}$ Century-the challenges. Jorind 10(2) ISSN 1596-8308

5. Kiggundu, E. and Nayimuli, S (2009). Teaching practice: A make or break phase for student teachers. South African journal of Education. 29:345-358.

6. Komba, S.C., \& Kira, E.S. (2013). The Effectiveness of teaching Practice in Improving Student Teachers' Teaching Skills in Tanzania. Journal of Education and Practice, 4(1), 157-163.

7. Koross, R. (2016). The student teachers' experiences during teaching practice and its impact on their perception of the teaching profession. Ira International Journal of Education and Multidisciplinary studies (issn 2455-2526), 5(2), 76-85.

8. Lawal, W, Adesengun \& Samson O (2015). socioeconomic Status of Teachers Quality and Job Performance in Secondary Schools.

9. Okobia, E.O., Augustine, O., \& Osagie, R.O (2013). An analysis of the perceived Challenges Faced by Student-teachers during Teaching practice Exercise. Journal of Education and Practice. 4(11)

10. Okolo I, A (2013). Teachers education: A panacea for successful transformation in Nigeria. A seminar paper presented at the 2013 National Conference of the Committee of provost of Colleges of Education in Nigeria. Abuja.

11. Samuel M (2010). Searching for a "Pedagogy of Hope": Teacher Education and social Sciences. Perspectives in Education, 28(1): 5-15

12. Saricoban, A. (2010). Problems encountered by student-teachers during their practicum studies. Procedia Social and behavioral Sciences 2(2010): 707-711

13. Tillema, H. H., Smith, K., \& Leshem, S. (2011). Dual roles, conflicting purposes: a comparative study on perceptions of assessment in mentoring relations during practicum. European Journal of Teacher Education, 34 (2), 139-159.

How to cite this article: Atsuwe, B. A, Nomji, E, V. Physics student-teachers' challenges during teaching practice in secondary schools and their solutions: a study of Federal University of Agriculture Makurdi. International Journal of Research and Review. 2021; 8(4): 245-251. DOI: https://doi.org/10.52403/ijrr.20210432 